\title{
Cost-benefit analysis of two culture methods that influence pearl production from the black-lip pearl oyster, Pinctada margaritifera
}

\author{
Bill Johnston ${ }^{1,2}$ @ | Damian Hine ${ }^{3}$ | Pranesh Kishore ${ }^{4,5}$ | \\ Paul C. Southgate ${ }^{5}$
}

${ }^{1}$ Queensland Department of Agriculture and Fisheries, Agriculture Division, Nambour, Queensland, Australia

${ }^{2}$ School of Science and Engineering, University of the Sunshine Coast, Sippy Downs,

Queensland, Australia

${ }^{3}$ UQ Business School, The University of Queensland, Brisbane, Queensland, Australia

${ }^{4}$ School of Marine Studies, University of the South Pacific, Suva, Fiji

${ }^{5}$ Australian Centre for Pacific Islands Research and School of Science and Engineering,

University of the Sunshine Coast, Sippy

Downs, Queensland, Australia

\section{Correspondence}

Bill Johnston, Queensland Department of Agriculture and Fisheries, 47 Mayers Road, Nambour, Queensland 4560, Australia. Email: bill.johnston@daf.qld.gov.au

\section{Funding information}

Australian Centre for International Agricultural Research, Grant/Award Number: FIS/2014/ 060
The black-lip pearl oyster, Pinctada margaritifera, used for round pearl production in Polynesia, is generally cultured using "ear-hanging" where they are attached to a rope to form "chaplets." In other countries, pearl oysters are cultured using panel (pocket) nets that are more expensive than chaplets but afford more protection to cultured oysters. Prior research has shown panel nets produce pearls of higher quality and value, potentially generating higher profits. This study used cost-benefit analysis to compare pearl production using chapletbased and panel net-based culture methods. Whole farm data, including gross revenues and annual production costs, fixed and variable, were analyzed. Average production cost per pearl using panel netbased culture was USD 22.47 and for chaplet-based culture was USD 21.55. However, use of panel nets saved around $3,430 \mathrm{hr}$ (USD 6,860 ) of labor a year, offsetting the greater capital investment. A chaplet-based pearl farm generated USD 65,738 in annual profits compared to USD 88,774 for a panel net-based farm. Positive cash flow was achieved 1 year earlier (Year 7) for the panel net-based farm. This is the first economic analysis of different pearl culture methods for $P$. margaritifera and evidence of profitability will support further development of the black-lip pearl industry in the Indo-Pacific region.

\section{KEYWORDS}

Fiji Islands, pearl culture, pearl economics, pearl-farming profitability, pearl quality 


\section{1 | INTRODUCTION}

Cultured round pearl production using the black-lip pearl oyster, Pinctada margaritifera, in Polynesia, relies primarily on collection of juvenile oysters from the wild using spat collectors (Arnaud-Haond et al., 2003, 2004; Southgate et al., 2008), and subsequent grow-out of the resulting oysters to pearl-producing size. Oysters are then "seeded" or "grafted" for pearl production (Blay et al., 2014; Taylor \& Strack, 2008), then typically cultured for a further 18-24 months before resulting pearls are harvested.

Pearl farmers have a number of options regarding the culture method and culture units, used to hold pearl oysters during the pearl production phase of their operation (Gervis \& Sims, 1992; Southgate, 2008). Perhaps, the simplest is the "ear-hanging" method that was adapted initially from the Japanese scallop culture industry (Gervis \& Sims, 1992). It involves drilling a small hole $(2-3 \mathrm{~mm})$ through the base of the pearl oyster shell in the dorsal-posterior region, which is used to attach the oyster to a rope using monofilament fishing line or wire (Gervis \& Sims, 1992; Southgate, 2008). A number of oysters are usually attached to a single rope, either singly or in pairs, to form a "chaplet" (Friedman \& Southgate, 1999; Ky, Blay, \& Lo, 2016), and chaplets are attached directly to either a raft or surface longline (Gervis \& Sims, 1992; Southgate, 2008). The advantages of this chaplet-based culture method include low setup and maintenance costs, because of greatly reduced equipment outlay, and improved water flow and food availability because oysters are not enclosed within a culture unit. Chaplet-based pearl oyster culture is widely practiced in French Polynesia and has provided a basis for a considerable volume of pearl industry-specific research, reported over recent years by the French Research Institute for Exploitation of the Sea (Ifremer) and associated agencies, working toward pearl industry improvement in French Polynesia (e.g., Ky et al., 2016 and related publications). Chaplet-based pearl oyster culture is well suited to the relatively protected atolls of Polynesia where predation is minimal. However, chaplet-based pearl oyster culture is less suited to other pearl culture regions where pearl oysters are exposed to both adverse environmental conditions and greater threats from predators such as fish, crustaceans, mollusks, and turtles (Humphrey, 2008; Pit \& Southgate, 2003). In Australia and southeast Asian countries, for example, pearl oysters are predominantly cultured using panel (pocket) nets that are made from strong steel or galvanized frames supporting mesh pockets that hold the oysters (Gervis \& Sims, 1992; Southgate, 2008).

Commercial round pearl production using P. margaritifera was established in Fiji in 2000, using spat collection and chaplet-based culture methods, similar to those used in French Polynesia (Kishore \& Southgate, 2016; Kishore, Vuibeqa, \& Southgate, 2018). Like French Polynesia, the overall quality of round pearls produced in Fiji is reduced by the occurrence of pearls with "circles" (Kishore \& Southgate, 2016); concentric depressions or grooves on their surfaces (Ito, 2009), which can considerably reduce the value of a pearl crop. In the Tuamotu Archipelago of French Polynesia, for example, circled pearls account for $23 \%$ of production volume but only $6 \%$ of their value (Ky, Demmer, Sham-Koua, \& Cabral, 2015). Prior research has shown that $P$. margaritifera cultured on chaplets produce a higher proportion of pearls with circles than oysters held in panel nets (Kishore \& Southgate, 2016). Pearl farmers seek to produce high quality "Agrade" round pearls (very high luster, very minor or no surface imperfections, and are bright and colorful) as opposed to other shapes and grades (A-D). The proportion of round-shaped pearls resulting from panel net-based culture was 6.25\% compared to $5.34 \%$ for chaplet-based culture, and panel net-based culture produced a much higher proportion of "A-grade" pearls (Kishore \& Southgate, 2016). This difference between culture methods was thought to result from increased byssus secretion by oysters held on chaplets because of their reduced stability compared to those in panel nets. The authors argued that pearls produced by pearl oysters held in panel nets would provide better returns and higher profit margins for pearl farmers, but they noted the greater capital outlays for infrastructure and potentially higher operational costs of this method, which may be prohibitory for prospective farmers (Kishore \& Southgate, 2016).

Whole-farm modeling supports the determination of setup and operational costs of round pearl farming in Fiji and can ultimately provide assessments of minimum viable farm size (Johnston, Hine, \& Southgate, 2018). The model does not include lease costs of marine production space, but includes land purchases for terrestrial operations. Such models allow prediction of the economic impacts of changes in culture methodology, a potentially valuable 
decision-making tool for pearl farmers (Saidi, Johnston, \& Southgate, 2017). While Kishore and Southgate (2016) confirmed that panel net-based culture of $P$. margaritifera resulted in improved pearl quality and value compared to chaplet-based culture, they also suggested that a detailed cost-benefit analysis of the two husbandry options would be beneficial to round pearl farmers. There are no prior reports in the primary literature assessing the relative economic benefits of different culture methods for round pearl culture from $P$. margaritifera. Based on a minimum farm size of approximately 50,000 mature oysters (Johnston et al., 2018), the aim of this study was to compare the relative economic benefits of pearl production in Fiji employing chaplet-based and panel net-based culture methods using cost-benefit analysis. Given the broad use of chaplet-based pearl oyster culture in a number of countries (Ky et al., 2016; Southgate, 2008), our results will have broad application in assisting both existing and prospective pearl farmers with decision-making about the appropriate culture method, in the context of upfront capital investment, technical skill level required and operational costs, and potential profits generated.

\section{2 | MATERIALS AND METHODS}

P. margaritifera are generally "seeded" for round pearl production using a single nucleus inserted into the gonad by a skilled technician (Taylor \& Strack, 2008). A culture period of 18-24 months is then required to produce a cultured pearl with appropriate nacre thickness (Blay et al., 2014). Once a pearl is harvested by a technician, a second nucleus can be inserted in to the existing pearl sac, to produce a second pearl (Demmer, Cabral, \& Ky, 2016; Kishore \& Southgate, 2015). This "reseed" process, referred to as "surgreffe" in French Polynesia, can be performed up to four times assuming appropriate quality pearls continue to be produced by an oyster. The economic model developed in this study used data generated by Kishore and Southgate (2016) that reported relative quality of pearls produced, from a first pearl harvest, by P. margaritifera cultured using both chaplet-based and panel net-based culture methods. The life of the pearl farms modeled in this study was set at 20 years, and, therefore, had to account for subsequent pearl reseeds. However, because Kishore and Southgate (2016) only reported the first harvest results, actual production quality data from other current Fijian pearl farms were used in the model to represent production from second, third, and fourth pearl harvests. These data accounted only for differences in operational and infrastructure costs between methods and did not account for pearl production differences between methods.

\section{1 | Data collection}

Data for this study were collected through a series of interactive workshops attended by pearl farmers and pearl industry stakeholders in Fiji, which yielded baseline pearl farm economic data reported by Johnston et al. (2018). The resulting data were used in this study to develop representative whole-farm economic models, based on cost-benefit analysis, comparing chaplet-based and panel net-based culture methods. A chaplet consists of 10 seeded oysters, each suspended by $25 \mathrm{~cm}$ of fishing line on a 1.5-m dropper rope from the main longline (Southgate, 2008). In comparison, panel nets hold eight oysters and are suspended directly from the main longline in a similar fashion. As detailed in the preceding section, the models were based on comparative pearl production data from chaplet-based culture and panel net-based culture reported by Kishore and Southgate (2016) and included gross revenue from pearl sales and annual production costs, both fixed and variable. From these data, the model generated comparative results for net present value (NPV), equivalent annual return (EAR, a derivative of NPV and a measure of annual profitability), internal rate of return (IRR), benefit-cost ratio, and payback period.

\section{2 | Modeling software and analysis}

The modeling software used in this study is an extension of a model developed by Johnston and Ponia (2003) for analysis of cultured round pearl production in Pacific island nations (Johnston, 2016; Johnston, Hine, Limpus, \& 
Voronina, 2014; Tisdell \& Poirine, 2008). The economic model used for the cost-benefit analysis incorporates a discounted cash flow analysis over a 20-year period to ensure the model achieves a steady state, given the complexity of the round pearl production system (Chen, Haws, Fong, \& Leung, 2017; Johnston et al., 2018; Saidi et al., 2017).

The economic model for round pearl culture uses a number of financial indicators to assess the viability of investment in a venture. The present value (PV) of the future stream of cost outflows and cash inflows over 20 years is calculated using the compound interest method. Subtracting the future sum of cost outflows from the sum of future cash inflows generates the NPV (Chen et al., 2017; Johnston et al., 2018; Saidi et al., 2017; Shang, 1990), and the annuity of this figure provides the EAR, a measure of annual profitability. This method is commonly applied when choosing among a range of investment or project options (Nas, 2016). The rate used to calculate PVs is known as the discount rate (opportunity cost of funds). For the purpose of this modeling exercise, the discount rate was set at $6 \%$, a reflection of the long-term domestic bond market in Fiji at the time of the study (cbonds.com, 2018). Additionally, the IRR provides an indication of the sensitivity of the project to changes in the discount rate, and is another financial indicator used in this study (Chen et al., 2017; Johnston et al., 2018; Saidi et al., 2017). More simply, the IRR represents the maximum rate of interest that could be paid on all capital invested in a project. For example, if all the funds were borrowed, and interest charged at the IRR, the borrower would break even, that is, recover the costs of the project. Thus, IRR is an important indicator of the investability of a venture.

Data inputs to the model include the costs associated with longline farming infrastructure (e.g., ropes, floats, anchors, etc.), pearl production and husbandry (e.g., panel nets or chaplets, pearl nuclei, pearl technicians, oyster cleaning tools etc.), marketing, and labor and farm operating costs. Values shown in this study are United States dollars (USD) with values calculated from actual costs in Fijian dollars (FJD) using an exchange rate of $1 \mathrm{USD}=2$ FJD.

\section{3 | Comparative economic models}

Kishore and Southgate (2016) implanted 600 oysters for pearl production; 300 were then held using the chapletbased method and 300 using the panel net-based method. Pearls were harvested after 18 months of oyster culture and graded (Kishore \& Southgate, 2016). The resulting pearl grades are described in Table 1, and these data provide a basis for the cost-benefit analysis comparison of the two culture methods undertaken in this study.

TABLE 1 The percentage (\%) of saleable pearls across grades (A, B, C, and D) and four pearl shapes resulting from chaplet-based and panel net-based pearl oyster culture methods, reported by Kishore and Southgate (2016)

\begin{tabular}{lllll} 
& Grade & & \\
\cline { 2 - 4 } Pearl shape $^{\text {a }}$ & A & B & C & D \\
Chaplet-based culture & & & & 0 \\
Round/semiround & 3.05 & 2.29 & 0 & 0 \\
Semibaroque & 0 & 16.41 & 47.33 & 0.38 \\
Circles & 0 & 11.07 & 1.53 & 17.94 \\
Baroque & 0 & 0 & & 0 \\
Panel net-based culture & & & 0 & 0 \\
Round/semiround & 6.25 & 0 & 0 & 0 \\
Semibaroque & 2.21 & 23.16 & 21.69 & 16.18 \\
Circles & 0 & 23.53 & 0 & 6.99 \\
Baroque & 0 & 0 &
\end{tabular}

a Pearl shape descriptions: round/semiround-a round pearl is one that is perfect, or close to perfect, spherical shape (diameter varies by $2-5 \%$ ); semibaroque-includes drop shapes, pear shapes, and oval and button shapes; baroque-have a distinctly irregular shape and are asymmetrical; circles-symmetrical pearl that has one or more parallel furrows running around the pearl perpendicular to its long axis (Strack, 2006). 
The average wholesale (raw pearl-without value adding) prices across grades and types of pearls used in this study are drawn from data supplied by Fijian pearl farmers. The market for round Fijian P. margaritifera pearls is considered "niche" where global demand exceeds supply, creating a market environment where pearl prices are relatively stable. The prices used in this analysis represent wholesale long-term averages (since 2011) for Fijian round pearls sold on the international market. Sale of value-added pearl products such as jewelry and handicrafts is not included in the analysis. All capital, variable, and fixed costs are also estimated based on data collected from stakeholder workshops, including follow-up one-on-one interviews with pearl farmers in Fiji.

The two different culture methods require a different level of investment and influence the operational costs of the pearl farm. Key economic inputs that vary between culture methods include capital investment, preparation and cleaning time for laborers, marketing (calculated as \% of revenue earned), and repairs and maintenance (\% of capital investment). Costs for panel nets were provided by the pearl farmer who operates the farm that collaborated in the study by Kishore and Southgate (2016), and who is experienced in both culture methods.

\section{\begin{tabular}{l|l}
3 & RESULTS
\end{tabular}}

A summary of the production and infrastructure inputs and key costs for the modeled chaplet-based and panel netbased farms is provided in Table 2. General differences in infrastructure and operational costs between the two culture methods impact a number of areas. The capital cost of making chaplets (USD 0.75) is less expensive than the upfront purchase of panel nets (USD 9.00). A key husbandry requirement for both culture methods is regular cleaning of oysters (removal of biofouling) to maintain their health (de Nys \& Ison, 2008). Cleaning of oysters is carried out every 2 months (six times per year) regardless of the culture method. Using panel net-based culture reduces the time (4 min per panel net) required to clean oysters, compared to chaplets (10 min), which reduces estimated annual farm labor costs by USD 6,861 (Tables 3 and 4). The cost of repairs and maintenance, calculated annually as a percentage of capital investment, is higher for the panel net-based farm (USD 7,008) compared to the chaplet-based farm (USD 4,500). International marketing costs of pearls is calculated as a percentage of annual gross revenue. The correlation between the pearl value and marketing cost stems from the reality that auction and brokering costs are set as a percentage of value, making them variable and linked to quality. Because of the improved shape and grade of pearls, the marketing cost is higher for the panel net-based farm (USD 8,544) compared to USD 7,611 for the chaplet-based farm (Table 4).

Repairs and maintenance costs, and marketing costs, were both calculated as direct percentages in the wholefarm modeling and vary directly with shifts in revenue and capital investment. While changes in repairs and maintenance, and marketing costs are important factors, it is the upfront expenditure (and future replacement costs) required for panel net-based culture, and the impact they have on labor resources that will likely influence a change in farming practice for round pearl farmers.

\subsection{Capital impacts}

The chaplet-based method had an initial capital outlay of USD 3,405, compared to panel nets that require an upfront investment of USD 49,394. Importation of panel nets to Fiji costs USD 6.80 per net with a total cost of USD 9.00, after duties and taxes. Considering the requirement for dropper ropes is the same for the two methods, in this study chaplets are costed on the basis of drilling (including labor) and materials only. Considering wear on the drill, drill bits, and electricity, the cost of each chaplet is set at USD 0.75. The traditional chaplet-based culture method is relatively inexpensive at establishment (USD 90,033) compared to panel net culture (USD 140,163). Annualized farm costs show that capital expenses (including upfront purchase and replacement costs over the 20-year life of the modeled farms) for chaplet-based culture (USD 12,538) are approximately half that of panel net-base culture (USD 24,033) (Table 4). 
TABLE 2 Production parameters, infrastructure, and other key costs and inputs used to develop whole-farm economic models for round pearl farming in Fiji

\begin{tabular}{|c|c|}
\hline Parameter & Number or value \\
\hline \multicolumn{2}{|l|}{ Production parameter } \\
\hline Total number of oysters on farm & 112,906 \\
\hline Number of seeded oysters on farm & 37,906 \\
\hline Production time (months) from seeding to harvest & 18 \\
\hline Seeding events per year & 2 \\
\hline Number of nuclei required annually & 27,915 \\
\hline Total hectares of farm production area & 7.95 \\
\hline Percent mortality of seeded oysters after first implant & $20 \%$ \\
\hline Percentage of saleable pearls in the first harvest & $50 \%$ \\
\hline Number of annual cleaning events & 6 \\
\hline \multicolumn{2}{|l|}{ Capital investment } \\
\hline Upfront capital required for chaplet-based culture & USD 90,003 \\
\hline Upfront capital required for panel net-based culture & USD 140,163 \\
\hline \multicolumn{2}{|l|}{ Culture infrastructure } \\
\hline Number of longlines required & 47 \\
\hline Number of buoys required & 470 \\
\hline Number of anchors required & 454 \\
\hline Number of chaplets required & 3,791 \\
\hline Number of panel nets required & 4,738 \\
\hline Total upfront cost of materials to build chaplets & USD 3,405 \\
\hline Upfront purchase cost of panel nets & USD 49,394 \\
\hline \multicolumn{2}{|l|}{ Labor } \\
\hline Number of seeding technicians required per event & 2 \\
\hline Seeding cost per oyster & USD 2.56 \\
\hline Number of farm laborers employed & 6 \\
\hline Weekly wage per laborer & USD 80 \\
\hline Annual drawings of owner & USD 7,500 \\
\hline \multicolumn{2}{|l|}{ Annual production costs } \\
\hline Chaplet-based culture & USD 187,958 \\
\hline Panel net-based culture & USD 196,033 \\
\hline \multicolumn{2}{|l|}{ Other infrastructure required } \\
\hline \multicolumn{2}{|l|}{ Land and buildings } \\
\hline \multicolumn{2}{|l|}{ Vehicles and boats } \\
\hline \multicolumn{2}{|l|}{ Diving equipment } \\
\hline Lab and seeding equipment & \\
\hline
\end{tabular}

\section{2 | Farm labor impacts}

The chaplet-based pearl farm (with approximately 50,000 mature oysters) employs six permanent staff to assist in the day-to-day operations of the farm. Table 3 summarizes the time required to build a chaplet or fill a panel net and maintain them (cleaning - removal of biofouling) each year. Both panel nets and chaplets are cleaned nine times over the production cycle of 18 months that is, cleaning events occur every 2 months, or six times per year. 
TABLE 3 Differences in annual labor resources for chaplet-based and panel net-based pearl culture methods required to construct (chaplet) or fill (panel net) pearl production apparatus and annual maintenance (cleaning removal of biofouling), and their costs for round pearl culture in Fiji

\begin{tabular}{|lll|} 
& Chaplet-based & Panel net-based \\
\hline Construction (min) & 24 & 8 \\
\hline Annual cleaning (min) & 60 & 24 \\
\hline Total number of apparatus on-farm & 4,541 & 5,488 \\
\hline Total labor minutes-build and clean & 381,444 & 175,625 \\
\hline Total labor hours-build and clean & 6,357 & 2,927 \\
\hline Cleaning labor cost & USD 12,715 & USD 5,854 \\
\hline Total annual farm labor cost & USD 30,540 & USD 23,679 \\
\hline
\end{tabular}

TABLE 4 Annualized cost structure (USD) for chaplet-based and panel net-based culture methods for round pearl-farming operations in Fiji

\begin{tabular}{lll}
\hline Commodity/activity & Chaplet-based & Panel net-based \\
\hline Spat (juvenile oysters) & 34,095 & 34,095 \\
\hline Nuclei & 18,362 & 18,362 \\
\hline Seeding technicians & 67,812 & 67,812 \\
\hline Farm labor & 30,540 & 23,679 \\
\hline Marketing & 7,611 & 8,544 \\
\hline Fuel and energy & 3,150 & 3,150 \\
\hline Repairs and maintenance & 7,008 \\
\hline Other operating & 4,500 & 9,350 \\
\hline Capital & 9,350 & 24,033 \\
\hline Farm total & 12,538 & 196,033 \\
\hline Total per pearl & 187,958 & 22.47
\end{tabular}

The Fijian wage rate used in this study is USD 2.00 per hour and, although the length of a typical working week can vary for pearl farm employees, a working week of $40 \mathrm{hr}$ was assumed in our modeling. Use of panel nets, compared to chaplets, saves an estimated 3,430 hr (USD 6,860) of labor per year over six cleaning events, equivalent to 1.8 laborers (Table 3).

\subsection{Economic modeling output summary and economic indicators comparative output summaries}

The comparative annual cost structures of chaplet-based and panel net-based pearl farms are shown in Table 4. The revenue generated from each farm is based on the same number of harvested pearls, which is 8,723 annually (Johnston et al., 2018). Based on the results from Kishore and Southgate (2016), shown in Table 1, the composition of the pearl harvest, in terms of pearl shape and grade, is improved when using panel nets. Table 5 describes the total annual harvest of saleable pearls, across pearl shapes, and apportioned revenues.

The average annual production cost per pearl, across all grades and shapes, is USD 22.47 for the panel net-based farm and USD 21.55 for the chaplet-based farm (Table 4). Average revenues per saleable pearl for the panel netbased farm and chaplet-based farm are USD 32.65 and USD 29.08, respectively (Table 5).

\subsection{Net present value}

NPV over the 20-year life of the project, using a discount rate of $6 \%$, is USD 754,005 for the chaplet-based farming operation, and USD 1,018,227 for the panel net-based operation. The model indicates that it would take 8 years to 
TABLE 5 Distribution of harvested pearls across graded shapes and associated annual revenues (USD) for chaplet-based and panel net-based pearl oyster culture methods

\begin{tabular}{|c|c|c|c|c|}
\hline \multirow[b]{2}{*}{ Pearl shape } & \multicolumn{2}{|c|}{ Chaplet-based } & \multicolumn{2}{|c|}{ Panel net-based } \\
\hline & Number & Gross revenue & Number & Gross revenue \\
\hline Round & 1,824 & 142,795 & 1,844 & 153,772 \\
\hline Semibaroque & 1,297 & 32,055 & 1,890 & 46,013 \\
\hline Circle & 4,103 & 38,313 & 3,205 & 28,398 \\
\hline Baroque & 1,499 & 40,532 & 1,744 & 56,624 \\
\hline Farm total & 8,723 & 253,695 & 8,723 & 284,807 \\
\hline Total per pearl & & 29.08 & & 32.65 \\
\hline
\end{tabular}

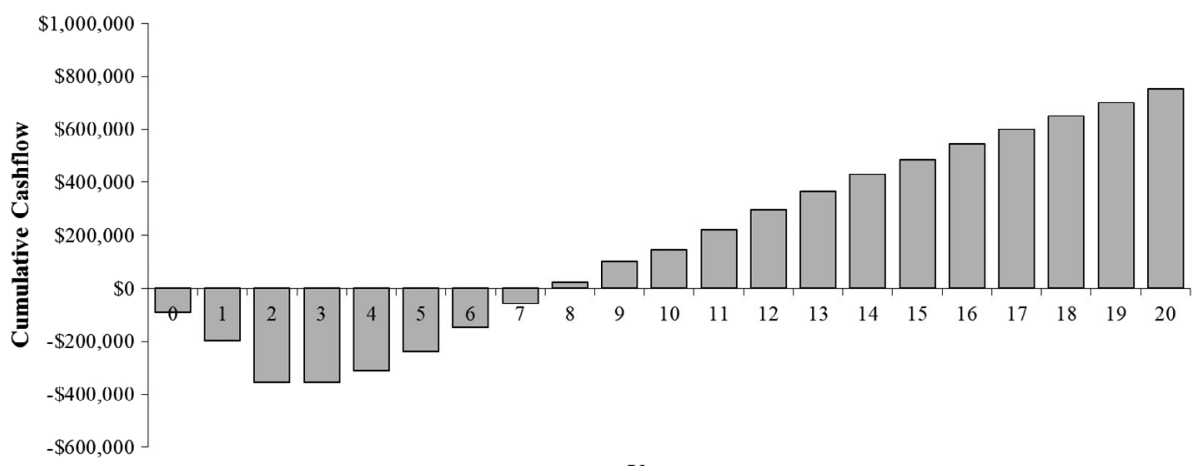

Year

FIGURE 1 Discounted cumulative cash flow for the chaplet-based round pearl-farming operation modeled in this study

recoup the original investment in the chaplet-based farm (Figure 1), and 7 years for the panel net-based farm (Figure 2).

\section{5 | Annual profitability}

Measurement of pearl farm profitability is based on EAR (EAR = annualized NPV) and IRR. The results of these analyses are shown in Table 6 with some additional economic indicators. For the chaplet-based and panel net-based farms, the EAR is USD 65,738 and USD 88,774 , respectively, IRR is $20.35 \%$ and $23.10 \%$, respectively, and the benefit-cost ratio (total benefits divided by total costs) is 1.35 and 1.45 , respectively, that is, every dollar invested in the chaplet-based farm would return USD 1.35 over the life of the farm. These figures present reasonable returns on investment, although what is presented in the model are operational values that do not account for the purchase price or lease cost of the space occupied by the farm.

\section{4 | DISCUSSION}

Economic information relating to establishment and maintenance costs, and potential profitability of pearl farming is very scarce (Tisdell \& Poirine, 2008). This is the first comparison in the primary literature of the relative economic benefits of pearl production by $P$. margaritifera using different culture methods. Results showed that pearl farming using both chaplet-based and panel net-based culture methods would recover the initial upfront capital investment and make a profit, supporting the viability of the two culture-based ventures. The payback period of the panel netbased farm ( 7 years) is 1 year ahead of the chaplet-based operation ( 8 years), despite higher upfront capital 


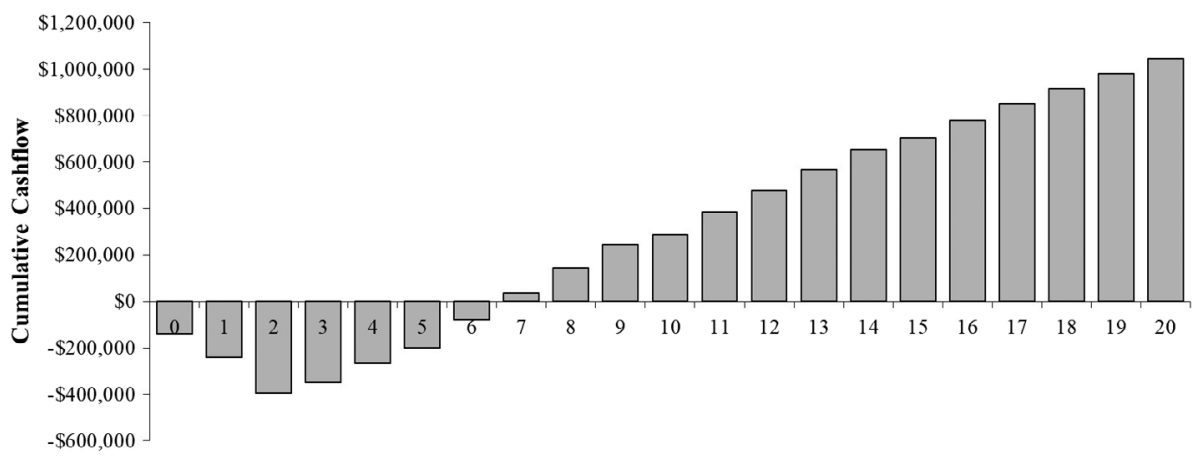

Year

FIGURE 2 Discounted cumulative cash flow for the panel net-based round pearl-farming operation modeled in this study

TABLE 6 Summary of profitability results and other economic indicators for chaplet-based and panel net-based pearl oyster culture methods in Fiji

\begin{tabular}{lll}
\hline Economic measure & Chaplet-based & Panel net-based \\
\hline EAR & USD 65,738 & USD 88,774 \\
\hline IRR & $20.35 \%$ & $23.10 \%$ \\
\hline Benefit-cost ratio & 1.35 & 1.45 \\
Payback period & 8 years & 7 years \\
\hline
\end{tabular}

EAR: equivalent annual return; IRR: internal rate of return.

investment and increased maintenance associated with panel net-based culture. In terms of annual profit, the panel net-based farm would generate an EAR 35\% higher than the chaplet-based farm. Kishore and Southgate (2016) showed that culture method has an impact on the shape and quality of resulting pearls, and on overall pearl grades. Substitution of these harvest results into the whole-farm viable scale model, described by Johnston et al. (2018), shows that panel net-based culture of P. margaritifera improved gross revenues by $12 \%$. As mentioned above, our economic modeling was based on pearl quality and production data from first seeded $P$. margaritifera (Kishore \& Southgate, 2016) and actual production data from other current Fijian pearl farms was used in the model to represent subsequent pearl production. This approach will likely underestimate the revenue generated using panel net-based culture, compared to chaplet-based culture. Size, quality, and value of cultured pearls generally improve subsequent to the first harvest (Kishore \& Southgate, 2015), and would likely further improve annual revenue streams for panel net-based culture compared to chaplet-based culture, beyond first pearl harvest.

Differences between chaplet-based and panel net-based pearl oyster culture are most evident for farm labor resources used in cleaning of culture apparatus, upfront capital purchase and replacement costs, marketing, and repairs and maintenance costs. Increases in marketing costs and repairs and maintenance costs are a linear function of the increase in revenues and capital costs of the operation. The panel net-based farm, compared to the chapletbased farm, had increased marketing costs (calculated as $3 \%$ of gross sales for both modeled farms) of $12 \%$, and higher repairs and maintenance costs of $56 \%$, based on the greater upfront purchase cost of panel nets. The upfront capital cost of purchasing and importing panel nets is USD 49,394 compared to the capital cost of constructing chaplets (USD 3,405). Total capital expenditure, including land, but excluding the lease cost of marine production space, for a panel net-based farm at inception is USD 140,163, of which panel nets comprise $35.2 \%$. In comparison, upfront capital expenditure for a chaplet-based farming operation is USD 90,003, of which chaplets compose $3.8 \%$.

Johnston et al. (2018) identified significant barriers to entry into round pearl farming in Fiji of relevance to the broader western Pacific. Many smaller operators struggle to access the capital they require to establish farms and 
overcome the significant cash flow lags that exist in the initial years of a round pearl-farming operation. Considering lower upfront capital investment, smaller operations are likely to maintain the traditional chaplet-based culture method, despite the higher potential long-term profitability of panel net-based culture. It may, however, be feasible to gradually replace chaplets and transition to panel net-based culture as the venture progresses toward profitability. In this way, the venture could reinvest returns, rather than rely on debt financing, which comes at a high interest rate (often 18-25\%) throughout the Pacific, which is similar to the IRR indicated in this study.

One of the major husbandry activities associated with marine pearl farming is removal of biofouling from oysters (de Nys \& Ison, 2008; Lacoste, Le Moullac, Levy, Gueguen, \& Gaertner-Mazouni, 2014; Pit \& Southgate, 2003). Most pearl farms in Fiji employ local indigenous laborers to remove epibionts attached to oyster shells and culture infrastructure. As chaplets comprise oysters attached to a dropper line, suspended from a longline, they are more difficult to handle and take longer to clean. Each chaplet takes $10 \mathrm{~min}$ to clean (1 min per oyster), while panel nets that hold oysters in pockets, within a rigid frame, require $4 \mathrm{~min}$ to clean (30 s per oyster). This efficiency gain in farm labor is significant and reduces annual farm labor cost by $22.5 \%$ (Table 3), or 1.8 full-time equivalent staff. While labor efficiency is not beneficial for local employment opportunities, particularly in rural Fiji, efficiencies gained here allow resources to be deployed to other areas of the pearl-farming operation such as collection of spat or juvenile oysters (Kishore et al., 2018), half-pearl production (Kishore, Hunter, Zeng, \& Southgate, 2014), or scaling-up the farm. Small family groups or coastal communities that operate small-scale pearl culture operations could benefit from panel netbased culture because the time saved, compared to chaplet-based culture, could be utilized elsewhere to support the family or community group (i.e., terrestrial farming, fishing, and other livelihood activities).

\section{5 | CONCLUSIONS}

Established and prospective pearl farmers in the Pacific have options regarding the culture methodology they adopt. Results of this study show that pearl production from P. margaritifera housed in panel nets provides direct long-term economic benefits, compared to traditional chaplet-based culture. While farm operating costs were similar between the two culture methods, labor efficiencies in panel net-based culture offset the higher capital, maintenance, and marketing costs of this culture method. The improved quality of first pearls from panel net-based culture provided a $12 \%$ increase in revenue, compared to chaplet-based culture, overcoming the greater annual operating costs (4.3\% higher than chaplet-based culture).

Establishment of a round pearl farm in the western Pacific would be better placed to utilize panel nets rather than chaplets, given the greater profitability that it generates over the longer term. However, investment decisions are not only guided by long-term profitability. Consideration must be given to entry barriers such as significant upfront capital investment and the reality that capital to fund pearl farms is inherently difficult to access, particularly in Fiji (Johnston et al., 2018). The fact that chaplet-based operations would generate over USD 65,000 in annual profits, compared to the average annual rural household income of USD 5,800 in Fiji (Fiji Bureau of Statistics, 2008-2009), does not make this investment choice redundant for potential entrants (Johnston \& Pickering, 2003).

\section{ACKNOWLEDGMENTS}

This research was supported by the Australian Centre for International Agricultural Research (ACIAR) and Fiji Fisheries Department within ACIAR project FIS/2014/060 "Developing pearl industry-based livelihoods in the western Pacific" led by P.C.S. at the University of the Sunshine Coast. Many thanks to the pearl farmers of Fiji and other stakeholders for their valued contributions to this study, particularly Justin Hunter of J Hunter Pearls, Fiji who made a valuable contribution to this study.

\section{ORCID}

Bill Johnston (D) https://orcid.org/0000-0001-8839-8006 


\section{REFERENCES}

Arnaud-Haond, S., Vonau, V., Bonhomme, F., Boudry, P., Blanc, F., Prou, J., ... Goyard, E. (2004). Spatio-temporal variation in the genetic composition of wild populations of pearl oyster (Pinctada margaritifera cumingii) in French Polynesia following 10 years of juvenile translocation. Molecular Ecology, 13, 2001-2007.

Arnaud-Haond, S., Vonau, V., Bonhomme, F., Boudry, P., Prou, J., Seaman, T., ... Goyard, E. (2003). Spat collection of the pearl oyster (Pinctada margaritifera cumingii) in French Polynesia: An evaluation of the potential impact on genetic variability of wild and farmed populations after 20 years of commercial exploitation. Aquaculture, 219, 181-192.

Blay, C., Sham-Koua, M., Vonau, V., Tetumu, R., Cabral, P., \& Ky, C. L. (2014). Influence of nacre deposition rate on cultured pearl grade and colour in the black-lipped pearl oyster Pinctada margaritifera using farmed donor families. Aquaculture International, 22(2), 937-953.

Chen, J. Q., Haws, M. C., Fong, Q. S., \& Leung, P. (2017). Economic feasibility of producing oysters using a small-scale Hawaiian fishpond model. Aquaculture Reports, 5, 41-51.

de Nys, R., \& Ison, O. (2008). Biofouling. In P. C. Southgate \& J. S. Lucas (Eds.), The pearl oyster (pp. 527-553). Amsterdam, the Netherlands: Elsevier.

Demmer, J., Cabral, P., \& Ky, C. L. (2016). Comparison of harvested rate and nacre deposition parameters between cultured pearls issued from initial graft and second nucleus insertion in P. margaritifera. Aquaculture Research, 47(10), 3297-3306.

Friedman, K. J., \& Southgate, P. C. (1999). Growout of blacklip pearl oysters, Pinctada margaritifera, on chaplets in suspended culture in Solomon Islands. Journal of Shellfish Research, 18, 451-458.

Gervis, M. H., \& Sims, N. (1992). The biology and culture of pearl oysters (Bivalvia: Pteriidae) (p. 38). Manila, Philippines: Overseas development administration and International Center for Living Aquatic Resources Management.

Humphrey, J. D. (2008). Disease and predation. In P. C. Southgate \& J. S. Lucas (Eds.), The pearl oyster (pp. 367-435). Amsterdam, the Netherlands: Elsevier.

Ito, M. (2009). Improving pearl quality by grafting and husbandry methods. Aqua Tips, 20, 1-8.

Johnston, W. (2016). Agbiz farm budgeting tools. Developed by: Queensland Department of Agriculture and Fisheries, Business Queensland web portal. Retrieved from https://publications.qld.gov.au/dataset/agbiz-tools-fisheries-aquaculture

Johnston, W., Hine, D., Limpus, S., \& Voronina, M. (2014). Building business skills and community based industry development in the Pacific, Fiji workshops 2013 (Rakiraki and Savusavu) Australian Centre for International Agricultural Research, pp. 52.

Johnston, W., Hine, D., \& Southgate, P. C. (2018). Economic modeling of round pearl culture in Fiji and assessment of viable farm size. Journal of Shellfish Research, 37(1), 79-91.

Johnston, W., \& Pickering, T. D. (2003). The economics of aquaculture in comparison with other rural development opportunities in Pacific Island countries. University of the South Pacific. Marine studies technical report, 2003/07, Fiji, pp. 24.

Johnston, W., \& Ponia B. (2003). Pacific Pearl Economic Model. Economic models for aquaculture and agriculture commodities. Queensland Department of Primary Industries and Fisheries. Secretariat of the Pacific Community, Noumea, New Caledonia.

Kishore, P., Hunter, J., Zeng, C., \& Southgate, P. C. (2014). The effects of different culture apparatuses and current velocities on byssus production by the black-lip pearl oyster, Pinctada margaritifera. Aquaculture, 434, 74-77.

Kishore, P., \& Southgate, P. C. (2015). Does the quality of cultured pearls from the black-lip pearl oyster, Pinctada margaritifera, improve after the second graft? Aquaculture, 446, 97-102.

Kishore, P., \& Southgate, P. C. (2016). The effect of different culture methods on the quality of round pearls produced by the black-lip pearl oyster Pinctada margaritifera (Linnaeus, 1758). Aquaculture, 451, 65-71.

Kishore, P., Vuibeqa, G. B., \& Southgate, P. C. (2018). Developing a national spat collection program for pearl oysters in the Fiji Islands supporting pearl industry development and livelihoods. Aquaculture Reports, 9, 46-52.

Ky, C.-L., Blay, C., \& Lo, C. (2016). Half-sib family effects on cultured pearl quality traits in the black-lipped pearl oyster Pinctada margaritifera: Testing for indirect benefits of polyandry and polygyny. Aquaculture International, 24, 171-182.

Ky, C.-L., Demmer, J., Sham-Koua, M., \& Cabral, P. (2015). Development of cultured pearl circles and shape after initial graft and second nucleus insertion in the black-lipped pearl oyster Pinctada margaritifera. Journal of Shellfish Research, 34(2), 319-328.

Lacoste, E., Le Moullac, G., Levy, P., Gueguen, Y., \& Gaertner-Mazouni, N. (2014). Biofouling development and its effect on growth and reproduction of the farmed pearl oyster Pinctada margaritifera. Aquaculture, 434, 18-26.

Nas, T. F. (2016). Cost-benefit analysis: Theory and application (p. 231). London, England: Lexington Books.

Pit, J. H., \& Southgate, P. C. (2003). Fouling and predation; how do they affect growth and survival of the blacklip pearl oyster, Pinctada margaritifera, during nursery culture? Aquaculture International, 11, 545-555.

Saidi, I., Johnston, B., \& Southgate, P. C. (2017). Potential profitability of pearl culture in coastal communities in Tanzania. Aquaculture Reports, 5, 10-17.

Shang, Y. C. (1990). Aquaculture economic analysis: An introduction (p. 211). Baton Rouge, LA: World Aquaculture Society.

Southgate, P. C. (2008). Pearl oyster culture. In P. C. Southgate \& J. S. Lucas (Eds.), The pearl oyster (pp. 231-272). Amsterdam, the Netherlands: Elsevier. 
Southgate, P. C., Strack, E., Hart, A., Wada, K. T., Monteforte, M., Carino, M., ... Wang, A. (2008). Exploitation and culture of major commercial species. In P. C. Southgate \& J. S. Lucas (Eds.), The pearl oyster (pp. 303-355). Amsterdam, the Netherlands: Elsevier.

Strack, E. (2006). Pearls (p. 707). Stuttgart, Germany: Rühle-Diebener-Verlag.

Taylor, J., \& Strack, E. (2008). Pearl production. In P. C. Southgate \& J. S. Lucas (Eds.), The pearl oyster (pp. 273-302). Amsterdam, the Netherlands: Elsevier.

Tisdell, C., \& Poirine, B. (2008). Economics of pearl farming. In P. C. Southgate \& J. S. Lucas (Eds.), The pearl oyster (pp. 473-495). Amsterdam, the Netherlands: Elsevier.

How to cite this article: Johnston B, Hine D, Kishore P, Southgate PC. Cost-benefit analysis of two culture methods that influence pearl production from the black-lip pearl oyster, Pinctada margaritifera. J World Aquacult Soc. 2019;50:510-521. https://doi.org/10.1111/jwas.12594 